\title{
A Global Public Good: The Linkage between Veterinary Medicine and the Sanitary Management of Food Hygiene
}

\author{
Andrés Cartín Rojas \\ Department of Animal Production, Faculty of Agronomy, School of Natural and Exact Sciences, State Distance University (UNED), \\ San José, Costa Rica. \\ Email: acartin@outlook.com
}

Received July $12^{\text {th }}, 2013$; revised August $9^{\text {th }}, 2013$; accepted August $15^{\text {th }}, 2013$

Copyright @ 2013 Andrés Cartín Rojas. This is an open access article distributed under the Creative Commons Attribution License, which permits unrestricted use, distribution, and reproduction in any medium, provided the original work is properly cited.

\begin{abstract}
Ensuring food safety is a key and crucial factor for those agro-exporting nations seeking to improve their competitiveness, opening new options for global markets and positioning their products at a better price. A number of international guidelines serve a reference framework for defining national public policies aimed to provide safe food to the population. Veterinary services act as guarantors in this process along all the manufacture and value chain. The public and private veterinary services are nurtured and amalgamate together to ensure the attainment of common goals; strengthen and foment a robust and efficient alimentary legislation by using the World Animal Health Organization's normative as a standard reference. In this conceptual paper, an appraisal about the interrelationship and the interconnection between veterinary professionals and the sanitary management of food hygiene is widely developed by reviewing relevant literature, and discussing current trends. The author adopts an inductive approach, designed to generate understanding and propositions about this relevant topic.
\end{abstract}

Keywords: Public Health; Sanitary Management; Food Hygiene; Veterinary Medicine

\section{Introduction}

Currently, pecuary sector accounts nearly $40 \%$ of global agricultural economy, providing employment to a total laboral force of millions of people and sustaining food security within a huge percentage to inhabitants with low income and purchasing power, belonging to the most vulnerable social sectors [1]. There is an expectation that in the next few decades, human population and food demand will increase parallel. Thus, sanitary food hazards will also rise concomitantly. Under this panorama, food industry has a social responsibility across the manufacturing process to provide and generate safe food. Whereas, governments should implement public policies aimed at controlling and preventing risk to consumer [2], avoiding commercial barriers closing is also crucial in order to assure fluency and maximization of international agricultural markets. National Veterinary Authorities and Private Veterinary Services amalgamate and work together to assure and guarantee the consecution of this common objective. Both entities conform the primary defensive line to audit, verify and validate the fulfillment of reference guidelines ruled by the World Trade Organization and the World
Organization for Animal Health.

Veterinary public health (VPH) is a holistic and multidisciplinary medical branch that binds and represents a variety of biological, legal, environmental, socioeconomic and cultural disciplines for the improvement of human life's quality at the poblational level. Consequently, VPH covers five different thematic fields: 1 ) improving animal health and genetics to increase the productivity and supply the growing demand for animal protein; 2) healthcare management of food ensuring innocuity through all the stages of the agroproductive chain; 3) the surveillance, prevention and control of transboundary animal diseases and zoonoses; 4) development of nidality and ecology of diseases studies for a better comprehension of epidemicological patterns in emerging diseases; and 5) the developing of animal biomodels research for understanding its counterpart on humans diseases [3]. Related to food security and safety, VPH considered two fundamental premises within any health management system. First, food security attempts free access and supply of safe and nutritious food for the entire population through the promotion of manufacturing processes with great economic importance along an agricultural value chain. Moreover, 
it also prevents and controls certain diseases of economic and epidemiological importance, ensuring that the general population could access food free of chemical, physical and microbiological contaminants [4].

An integrative approach about the mutual relationship between sanitary management of food hygiene systems and veterinary public health will be covered in this literature review paper, which clarify and widely encompass diverse topics, such as the importance of alimentary legislation for a sustainable and adequate access to nourishment as a fundamental human right, or the contribution that veterinary medicine brings out to consolidate and toughen transparency, optimization and objectivity on international trade of animal products.

\section{Veterinary Public Health and Food Innocuity: Its Importance to Manage Foodborne Diseases}

Food innocuity is an element, which altogether with nutritional, physicochemical, commercial and organoleptic characteristics integrates aliment's quality. Usually is contextualized as the warranty that aliment ingested, won't represent an authentic hazard to consumers. Thereby, a complete grasp of sanitary food management programs only could be successful, if they base their approach on risk prevention and control, which requires an active, multidisciplinary and integrative commitment of all the political actors involved along the entire food chain.

The main burden of foodborne diseases (FBD) corresponds to microbiological pathogens related to animal by-products, followed by the presence of drug's residues and metabolites frequently used in animal production, such as, antibiotics and antiparasitic compounds. Considering that a broad range of foodborne diseases are actually food zoonoses, obviously the goals of public and animal health overlaps, resulting in a duality of the veterinary functions. As a result, there is a growing need for public policies aimed to ensuring food safety worldwide, specially due to an increasing number of food poisoning incidents that strongly hit the international agricultural market (for example, the presence of dioxins in shellfish products in the 90s [5], or the detection of high concentrations of melanin in milk for infants from China a few years ago, etc.), and the emergence of previously unknown diseases with a transmitted by the ingestion of contaminated nourishment, such as Bovine Spongiform Encephalopathy (BSE).

Food safety is therefore, a complex concept that embraces not only public health aspects, but also the general welfare of the population and access to international markets; overlying an important socio-economic component as well. Foodborne diseases generate a significant risk to consumer's health. For example, the Centers for Disease Control and Prevention (CDC) estimated that every year, approximately 48 million new cases of foodrelated illness, 9000 deaths, 128,000 hospitalizations and a total economic burden among 51.0 - 77.7 billion, only in the United States [6]. Nowadays, there is an increasing perception among US consumers that imported products of animal origin from foreigner countries are the main aetiology of these FBD. Bacterial diseases (for example, Campylobacteriosis, Salmonellosis, Clostridium perfringens infections, etc.) seem to be the major microorganisms involved in foodborne diseases outbreaks [7].

The economic and social impact from closing international supplies markets due to an inefficient food inocuity management system may be monumental, generating a concerning threat to developing countries economy's which rely a great percentage of their trade on agricultural products. Previously we have witnessed the imposition of nontariff barriers to animal products by business partners who argue the failure of basic food safety requirements, control and prevention, guidelines and auditory protocols that should be conducted by qualified professionals able to perform these tasks. Charges typically established within the functions of veterinarians, managers quintessential of food safety and public health.

A fluid international trade allows a dynamic factor of economic growth as a constant source of output and employment [8]. However, an eventual commercial border closures compromises the food security of its inhabitants, mainly social sectors with lower purchasing power. For example, data from the United Nations Organization for Food and Agriculture (FAO), shows that in Latin American starvation affects 49 million people $(8.3 \%$ of its total population) [9], where a widespread amount of countries are primarily agricultural exporters, causing that their economies need to be adjusted to the external forces of international markets. The closure of non-tariff barriers, will force to increase the importation of agricultural commodities, generating a huge impact in terms of food security and nutrition, by uprising the standard price of basic foodstuffs and mostly affecting poor people which have little access to nutritious and safe food. Although it seems to be an economic problem, actually it is a problem of Veterinary Public Health, aimed at meeting the bylaws of the World Declaration on Food Security and the Action Plan of the World Food Summit.

\section{International Organisms Related to Veterinary Public Health and the Sanitary Management of Food Animal Products}

Statutory Veterinary Services in each country are governed through regulations issued by the World Organization for Animal Health (OIE). In 1995, the Agreement on the Application of Sanitary and Phytosanitary Measures (SPSA) of the World Trade Organization (WTO) established the legal framework to regulate and normalize 
international trade of food animal by-products. The SPS Agreement recognizes the OIE regulations (SPSA Art. 3 on Harmonization and Annex A, paragraph 3-b), as the worldwide general standard for sanitary measures relating to animal health, food safety of animal products, animal welfare and zoosanitary prophylaxes [10].

A large number of countries that are OIE members, are themselves WTO signatories; bearing engagement to meet several regulations issued under the SPSA and basing their sanitary public policies on the OIE international standards and scientific risk analysis (for more information refer to Title 2 of Terrestrial and Aquatic OIE's Codes). The Terrestrial and Aquatic OIE's Codes, have the primary objective of facilitating and promoting international food trade, while offering recommendations to safeguard their inocuity. Both documents are indispensable for the Veterinary Authorities, and all the stakeholders involved in activities related to the manufacture, handling, transportation and commercialization of animal by-products. By adopting OIE standards as the legal basis for sanitary measures and executing it as an early alert biosecurity system [11], countries have strong and meaningful guarantees for a trustworthy commercial management of meat, dairy, poultry, apiarian and aquaculture by-products.

Veterinarians have an active and pivotal role in global food markets, participating as trade negotiators under the auspices of General Agreement on Tariffs and Trade (GATT), which is also a jurisprudential framework of WTO [12]. In addition to the normative above mentioned, the Codex Alimentarius Commission (CAC), a joint entity between FAO and WHO, have developed directives and principles related to hazard control by improving food safety and assuring suitability of products from nonanimal origin. However, the CAC and the OIE have implemented synergies, strategies and mechanisms to coordinate and integrate their activities in the field of animal by-products security systems along the manufacture and value chain, focused on maximizing productivity and securing food safety to consumers. Some examples are [13]:

- Code of Hygienic Practice for Eggs and Egg Products (CAC/RCP 15-1976).

- Code of Practice for Fish and Fishery Products (CAC/ RCP 52-2003).

- Code of Hygienic Practice for Milk and Milk Products (CAC/RCP 57-2004).

- Code of Hygienic Practice for Meat (CAC/RCP 582005).

- Code of Practice to Minimize and Contain Antimicrobial Resistance (CAC/RCP 61-2005).

- Principles Food Import and Export Inspection and Certification System (CAC/GL 20-1995).

- Principles for traceability/product tracing as a tool within a food inspection and certification system (CAC/GL 60-2006).

- Principles for risk analysis for food safety for application by governments (CAC/GL 62-2007).

- Guidelines for the design, operation, assessment and accreditation of food import and export inspection and certification systems (CAC/GL 26-2007).

- Guidelines for the validation of food safety control measures (CAC/GL 69-2008).

- Guidelines for the design and implementation of national regulatory food safety assurance programs associated with the use of veterinary drugs in food producing animals (CAC/GL 71-2009).

The SPS Agreement grants governments the rights to restrict food trade for sanitary purposes, assuring the restrictive measures implemented are based on scientific principles. The National Veterinary Authorities (for example. APHIS in the US, SAGARPA in Mexico, or SENASA in Costa Rica) have the primary function to establishing, implementing and enforcing regulations stipulated by the OIE guidelines in their territories, to ensure food hygiene to consumers and offering a fair international trade.

Innocuity food programs conducted by veterinary professionals are actually, inclusive public policies that integrates and nurture a plurality of health and social programs by actively training all stakeholders involved in each of the different phases of the food chain, especially in issues such as: 1) food handling; 2) traceability; 3) good agricultural practices; 4) good manufacturing practices; 5) organizational systems for control and management food hygiene; 6) disclosure and education depending on local consumption habits; 7) the slaughter, manufacture, storage and transportation of meat, poultry and dairy products; 8) zoonotic disease control in slaughterhouses; 9) inspection of animal products for national consumption, as for export as well; 10) to offers an comprehensive legal advice through consumption chain; 11) and the development of risk analysis systems which establishes the Microbiological Criteria (MC), the Safety food (FSO), the Appropriate Level of Protection (ALOP) and Performance Objectives (PO), four relatively new concepts introduced in the context of risk analysis that complement the operational management of food safety, which the United Nations Organization for Food and Agriculture (FAO) and the World Health Organization (WHO) are fostering legislation with a transversal viewpoint $[14,15]$.

Nowadays veterinary services worldwide, broadly uses and promote the implementation of hazard analyses and critical control points (HACCP) to achieve preventive management and control of food products (chapter 2.1 of the Terrestrial and Aquatic OIE's Code). The development of systems based on risk control and prevention, 
using hazard assessment techniques is recommended on the chapter 6.1 of the Terrestrial and Aquatic OIE's Codes.

\section{Veterinary Public Health, Food Safety and International Trade}

The implementation of public health policies based on the OIE's normative, has leaded to change the traditional governance arrangement in terms sanitary management systems, in order to be replaced by more sophisticated protocols that involves a complete integration of all stakeholders implicated in the processing food sector (commerce private organizations, livestock producers, transforming industries, etc.) which have the primary responsibility of guarantee food of enough quality and safety for consumers. As a result, the main objective of veterinary services is to establish innocuity patterns to regulate the manufacturing process and accomplish the suitability of final products, by auditing and assurance that the procedures used by the private food sector are reliable, have been validated and applied in accordance with the relevant rules national's legislation.

In this context, the modern approach to the SPV is essential for better understanding the new challenges that food production will face in the next few decades, by playing a crucial and indispensable role in terms of food security. Currently, there is an expected increase in global food demand by 2050 with an annual growth rate of around $4 \%$ on animal by-products [16]. Studies on trends in global livestock production, done by the United Nations Organization for Food and Agriculture (FAO), estimated that developing countries will significantly increase the demand for animal products. For example, there is the expectation that beef and milk production, which in 2005 was 265 and 243 million tons respectively, will be increased to 310 and 747 million tons by 2014 [17]. Subsequently to the increasing of food demand, the requirements and non-tariff barriers to products will also expand; inducing that food hygiene and consumer protection will be critical factors for accessing animal commodity markets globally.

Currently the American Continent is well positioned to accomplish the future food demands, bearing real options of increasing production. Latin American nations are worldwide in top of poultry and meat production, at third place in pork and the second in milk yield, protruding some countries like Argentina, Brazil, Chile, Costa Rica, Mexico, and Uruguay. In this sense, the current economic trends around the markets globalization, the increase in human population density and the subsequent increase on food demand, generates that the incoming decades regulatory services will have plausible and real challenges, bringing about that veterinary public and private professionals should nourish each other to successfully fulfill and satisfy the general management expectations at the food business sectors.

Contrastingly and despite the increase in the demand on animal protein, demographic projections, technological development and international trade of agricultural products, socioeconomic screenings shows that access to food in the poorest countries will deteriorate and aggravate. Therefore, public policies on animal health and production must take into account production systems, vulnerable social sectors and mechanisms to collect, store, process and distribute food. Promoting a qualified sanitary management policy of food safety carried out by the National Veterinary Authority, based on an adequate, robust and efficient food traceability system, that engages all stakeholders in the manufacturing process and its production stages which veterinary services has a continuous regulatory control, is imperative. Thus, aliment accessibility and innocuity will become an important responsibility for governments to guarantee the right of every human being to an adequate level of living, health and wellbeing.

\section{Interrelationship and Interdependence of the National Veterinary Authority and the Private Veterinary Services to Improve the Sanitary Management of Food Hygiene}

The World Animal Health Organization recognizes two types of veterinarians. The National Veterinary Authority (NVA); qualified state professionals who have the responsibility of supervising and monitoring the implementation of protective measures for animal health and welfare, veterinary certification procedures, as well as implementing another OIE's standards and recommendations. In the other hand, are the Private Veterinary Services (PVS), who accomplish delegated functions by applying the guidelines established by the OIE, serving as an extension of the NVA at the agro-industrial sector, and acting also under surveillance, accreditation and the approval of state veterinarians.

In addition, PVS should respect the fundamental principles and recommendations for assessing the objectivity, transparency and compliance to the reglamentary guidelines (more information, in the chapters 3.1, 3.2 of the Terrestrial and Aquatic's Code and the OIE's Evaluation Tool of Performance for Veterinary Services). The responsibilities and chain of command within the PVS should be clearly defined and documented properly. In each country, the National Veterinary Authority should establish and develop an appropriate institutional framework for private professionals to follow and implement the necessary policies and normatives, allocating suffi- 
cient financial and logistical resources to carry out their tasks in a sustainable manner. The NVA should also collaborate with other health and food agencies in the formulation and implementation of sanitary policies and multidisciplinary food safety programs to improve a coordinated and integrated risk communication.

Confidence on VPS is an important a cornerstone element to assure international trade. Veterinarians not only need to be able to detect and manage quickly and efficiently diseases listed by the OIE, including those with great risk in terms of public health, but also must provide effective guarantees on food inocuity through veterinary certificates. Preserving trust between trading partners depends on the ability of the VPS to fulfill these regalmentary functions. Ensuring transparency in disease reports, to promote efficiency in sanitary food management and reliability of veterinary certification is the key to provide commercial partners the necessary guarantees required to strengthen international food trade [18]. The Technical Forum of the Transboundary Diseases of Veterinary Importance running by the American Institute for Cooperation on Agriculture (IICA), held in San José, Costa Rica in 2007, emphasized that globalization trends of pecuary input markets will demand in the future, better and broader health certification systems. Consequently, NVA and VPS should be proactive and efficient in order to embracing sanitary food management systems by improving the interconnective relationship between stakeholders on four key components: 1) technical capability; 2) the human and financial resources; 3 ) interaction between private and public sectors; and 4) access to international agricultural markets [19].

Currently, NVA due to increasing on budgetary restrictions worldwide have lost the ability to absorb new normative activities, frequently delegating more responsibilities to VPS. Thus, the natural global tendency is to rely and deputize on private professionals to support and strengthen control and supervision of surveillance programs focused on priority diseases and establishing trade insurance between countries. Hence, government and food industry should work together by delegating the implementation of public health policies and technical assistance on private veterinarians, for the standardization, control, audit and coordination of hygiene food systems. Additionally, a dynamic mechanism of fluid communication which private veterinarians reports to government relevant epidemiological and innocuity incidents on a regular basis, should be also executed [20]. The integration of private veterinarians in the national network of health management is an essential step in the process of improving veterinary services's quality. Thereby, is imperative that countries looking for new food international markets or are integrating important commercial blocks (for example, EU, PARTA, SICA, MERCOSUR,
$A E C$, etc.), adapt their legislation to allow a progressive evolution of the official veterinary professionals in accordance with current international tendencies [21,22].

A reliable veterinary governance system must have independence, providing hierarchization and durability of technical decisions by allowing the management of longterm public health policies. Under this framework, vetrinary certificate is an important business tool, which affords trust between trading partners in any commercial transaction at nationally, regionally and internationally level. Thus, pyramidal structures between health professionals are required to achieve a trustful veterinary certification level. In all cases, the application of fundamental principles to ensure public health will remain ultimately responsible for the National Veterinary Authority [23]. Accordingly, administrative structures overseen by a single centralized authority which each stakeholder shall participation in the development and implementation of public policies are generated [24]. Thus, governments provide a network of competent, independent logistically of $a d$ hoc agents. In fact, the vast majority of first world countries, encourage and promote the emergence of a private sector with an institutional basis for the provision of a veterinary services more consequential, objective, suitable, effective and transparent in terms to ameliorate food safety and international trade of animal products [25].

\section{Accomplishing with Alimentary Regulations: From Theory into Practice}

The Universal Declaration of Human Rights establishes sustainable access to food (Art. 5 and 25, subsection 1) [26]. Similarly, the United Nations Committee on Economic, Social and Cultural Rights (CESCR) proposes that food must be healthy, devoid of toxic elements and pollutants, arguing that the right to an adequate alimentation is realized when every person has access to a sufficient quality and availability of nutrients to meet the individual requirements, free from adverse substances and being acceptable within cultural traditions [27]. Additionally, the Additional Protocol to the American Convention on Human Rights (Art. 12), determines that the purpose of eradicate malnutrition among the States Parties, is to improve secure food methods of production, supply and distribution, by promoting international cooperation and national policies on food hygiene [28]. Under this premise, veterinary profession must be supported by an effective legislation, in order to fully develop these transcendental assignments.

The Global FAO/WHO Forums on Food Safety Regulatory Authorities inferred that an effective food hygiene system consists of two main areas: 1 ) the responsibility of producing safe aliment supplies; and 2) the govern- 
ment's obligation to foster that this obligation is carry out adequately. Although is a primary responsibility of the alimentary industry to provide safe and suitable food by using hygienic practices and controlling food hazards, governments must also generate adequate safeguards to protect consumers [29] from FBD and guarantee reliability on pecuary markets. Official control services should be in a good position to enforce relevant regulations, with an organizational structure and plausible sanitary food safety management systems [30]. Therefore, the main task of the supervisory authorities (veterinary professionals) is to establish innocuity guidelines and enforcing an appropriate hygiene control system by livestock producers, processors and food traders [31], in accordance with the social, economic, cultural, religious and political contexts of the country.

Thereupon, alimentary legislation is an essential tool for strengthening sanitary management of food hygiene [32]. In legal matters on health and nutrition, it is important that normativity provides adequate safeguards to facilitate ongoing communication between veterinarians and other government institutions, contemplating a common scope. The regulatory framework must be translated into concrete actions, which depends on cooperation with all stakeholders, including the definition of roles and responsibilities, rights and obligations as well. Furthermore, the applicability of theoretical conceptualizations and agroeconomical concepts in trade and biosecurity of transboundary animal diseases, such as zoning and compartmentalization, depends on an effective collaboration between producers and veterinary services.

\section{Conclusion}

Sanitary management of food hygiene programs requires a high level of interaction and communication among stakeholders regarding to risk management, control and prevention. Currently trends towards increasing food exportations, combined with awareness by consumers, are increasingly necessary to ensure safety on food traded. Additionally, alimentary legislation is a critical, essential and pivotal infrastructural tool to outfit food safety sanitary programs, ensure social accessibility and palliate poverty in all countries. Nowadays, in many signatory nations of OIE's standards, veterinary professionals (officials and privates) are responsible for managing, developing and implementing integral, pragmatic and tangible public health policies. Consequently, food industry is going to profess more social responsibility on the incoming decades, necessitating that public and private regulatory veterinary authorities work together, in order to assume functions of verification, audit and certification across all the manufacturing and value chain.

\section{REFERENCES}

[1] S. B. Cáceres, "The Roles of Veterinarians in Meeting the Challenges of Health and Welfare of Livestock and Global Food Security," Veterinary Research Forum, Vol. 3, No. 3, 2012, pp. 155-157.

[2] B. J. Butain, "Emerging Challenges in Public Health Protection, Food Safety, and Security: Veterinary Needs in the USDA's Food Safety and Inspection Service,” Journal of Veterinary Medical Education, Vol. 31, No. 4, 2004, pp. 334-340. doi:10.3138/jvme.31.4.334

[3] R. J. Romero and L. C. Villamil, "Servicios de Salud Publica Veterinaria en Países en Desarrollo: Lineamientos para la Reestructuración,” Revista de Salud Pública, Vol. 1, No. 1, 1999, pp. 29-42.

[4] L. C. Villamil and J. R. Romero, "Retos y Perspectivas de la Salud Pública Veterinaria,” Revista de Salud Pública, Vol. 5, No. 2, 2003, pp. 109-122.

[5] C. E. Mercado, "Los Ámbitos Normativos, la Gestión de la Calidad y la Inocuidad Alimentaria: Una Visión Integral,” Agroalimentaria, Vol. 13, No. 24, 2007, pp. 119-131.

[6] R. L. Scharff, "Economic Burden from Health Losses Due to Foodborne Illness in the United States," Journal of Food Protection, Vol. 75, No. 1, 2012, pp. 123-131. doi:10.4315/0362-028X.JFP-11-058

[7] E. Scallan, R. M. Hoekstra, F. J. Angulo, R. V. Tauxe, Widdowson, S. L. Roy, J. L. Jones and P. M. Griffin, "Foodborne Illness Acquired in the United States-Major Pathogens,” Emerging Infectious Diseases, Vol. 17, No. 1, 2011, pp. 7-15.

[8] J. Gonzáles, "Sistemas de Rastreabilidad Para Productos de Origen Animal en Costa Rica,” Master Dissertation, Instituto en Enseñanza e Investigación en Ciencias Agrícolas, México City, 2004.

[9] FAO, "Panorama de la Seguridad Alimentaria y Nutricional en América Latina y el Caribe,” Subdivisión de Políticas y Apoyo en materia de Publicaciones, Roma, 2012.

[10] G. Brückner, C. Bruschke, S. Edwards and B. Vallat, “The OIE Network of Reference Laboratories," Journal of Wildlife Diseases, Vol. 43, Suppl. 3, 2007, pp. S60S63.

[11] J. K. Waage and J. D. Munford, "Agricultural Biosecurity," Philosophical Transactions of the Royal Society Biological Sciences, Vol. 363, No. 1492, 2008, pp. 863876. doi:10.1098/rstb.2007.2188

[12] C. Brown, I. Carbajal and G. Wagner, "Preparing the Veterinary Profession for Corporate and Trade Issues in the Americas: Proceedings of a Conference on Synergism and Globalization, Santiago, Chile, 6-8 May 2001," Journal of Veterinary Medical Education, Vol. 28, No. 2, 2001, pp. 56-61. doi:10.3138/jvme.28.2.56

[13] S. A. Slorach, “Assuring Food Safety: The Complementary Tasks and Standards of the World Organization for Animal Health and the Codex Alimentarius Commission," Revue Scientifique et Technique de l'Office International des Epizooties, Vol. 25, No. 2, 2006, pp. 813821. 
[14] C. de Swarte and R. A. Donker, "Towards an FSO/ALOP Based Food Safety Policy,” Food Control, Vol. 16, No. 9, 2005, pp. 825-830. doi:10.1016/j.foodcont.2004.10.023

[15] E. Carasco, A. Valero, F. Pérez-Rodríguez, R. M. GarcíaGimeno and G. Zurera, "Food Safety Risk Management," In: Savino, M., Ed., Risk Management in Environment, Production and Economy, InTech Press, Zagreb, 2011, pp. 77- 102. doi: $10.5772 / 17757$

[16] D. M. Morens, G. Folkers and A. S. Fauci, "The Challenge of Emerging and Re-Emerging Infectious Diseases,” Nature, Vol. 430, No. 6996, 2004, pp. 242-249. doi:10.1038/nature02759

[17] M. V. Terán and L. del Barrio, "Salud Pública Veterinaria e Inocuidad de los Alimentos en América Latina y el Caribe," Proceedings of Global Feed \& Food Congress, Sao Paolo, 2005, pp. 1-17.

[18] M. A. Larach, "El Acuerdo Sobre la Aplicación de Medidas Sanitarias y Fitosanitarias: Contenido y Alcance Para América Latina y el Caribe,” Naciones Unidas, Santiago de Chile, 2003.

[19] V. Arrúa, "Los Servicios Veterinarios Oficiales: Lecciones Aprendidas en las Américas," Memorias Foro Técnico del IICA: Enfermedades Transfronterizas: Importancia de los Servicios Veterinarios, la Acción Intersectorial y la Compensación, San José, 2007, pp. $11-22$.

[20] S. A. Moura, M. Bedoya, M. P. Agudelo, "Relations between Official and Private Veterinary Services in Epidemiology and the Control of Contagious Diseases," Revue Scientifique et Technique de l'Office International des Epizooties, Vol. 23, No. 1, 2004, pp. 79-93.

[21] Y. L. Brun, “Lignes Directrices de l’OIE (Organisation Mondiale de la Santé Animale) en Màtiere d’Organisation des Services Vétérinaires et de Leurs Relations Avec les Partenaires Privés, en Particulier Dans les Pays en Voie de de Développment," Revue Scientifique et Technique de l'Office International des Epizooties, Vol. 22, No. 2, 2003, pp. 561-567.

[22] A. Thiermann, "Adapting Veterinary Infrastructures to Meet the Challenges of Globalisation and the Requirements of the World Trade Organization Agreement on Sanitary and Phytosanitary Measures,” Revue Scientifique et Technique de l'Office International des Epizooties, Vol. 23, No. 1, 2004, pp. 109-114.
[23] P. P. Pastoret and D. Chaisemartin, "The Importance of Governance and Reliable Veterinary Certification,” Revue Scientifique et Technique de l'Office International des Epizooties, Vol. 30, No. 1, 2011, pp. 347-352.

[24] L. Hallet, "Collaboration between Official Veterinarians, Private Veterinarians and Livestock Producer Organisations," Revue Scientifique et Technique de l'Office International des Epizooties, Vol. 22, No. 2, 2003, pp. 523-532.

[25] Y. L. Brun, "Mechanisms for Collaboration between Public and Private Veterinarians: The Animal Health Accreditation Mandate," Revue Scientifique et Technique de l'Office International des Epizooties, Vol. 23, No. 1, 2004, pp. 69-77.

[26] ONU, "Declaración Universal de los Derechos Humanos," 1948. http://www.un.org/es/documents/udhr/

[27] C. Golay, "Derecho a la Alimentación y Acceso a la Justicia: Ejemplos a Nivel Nacional, Regional e Internacional,” Subdivisión de Políticas y Apoyo en Materia de Publicación Electrónica de la División de Comunicación de la FAO, Roma, 2009.

[28] OEA, "Protocolo Adicional a la Convención Americana Sobre Derechos Humanos en Materia de Derechos econÓmicos, Sociales y Culturales, Conocido Como Protocolo de San Salvador," 1988. http://www.oas.org/juridico/spanish/tratados/a-52.html

[29] L. C. Castellanos, L. C. Villamil and J. R. Romero, "Incorporación del Sistema de Análisis de Peligros y Puntos Críticos de Control en la Legislación Alimentaria," Agroalimentaria, Vol. 6, No. 3, 2004, pp. 289-301.

[30] FAO, "Establecimiento de Sistemas Eficaces de Inocuidad de los Alimentos,” Actas Segundo Foro Mundial FAO/OMS de las Autoridades de Reglamentación Sobre Inocuidad de los Alimentos, Bangkog, 2004, pp. 1-26.

[31] FAO, "Mejora de la Eficiencia y Transparencia en los Sistemas de Inocuidad de los Alimentos: Compartir Experiencias,” Actas Primer Foro Mundial FAO/OMS de las Autoridades de Reglamentación sobre Inocuidad de los Alimentos, Marrakech, 2002, pp. 1-245.

[32] J. Vapnek and M. Spreij, "Perspective and Guidelines on Food Legislation, with a New Model Food Law,” Development Law Service FAO Legal Office, Rome, 2005. 